\title{
Green mediated synthesis of silver nanoparticles using Ipomoea quamoclit to explore the potential antimicrobial activity against human pathogens

\author{
Manikandan Kathirvel ${ }^{* a}$, Kannaki Pasupathi ${ }^{b}$, Sivajothi Dhamodaran ${ }^{b}$, Sushmitha Selvakani ${ }^{b}$, Kabilan G
}

Mariappan $^{\mathrm{b}}$

aDepartment of Life Sciences, Kristu Jayanti College, Bangalore, Karnataka, India

${ }^{b}$ Department of Biotechnology, Sri Kaliswari College, Sivakasi, Tamil Nadu, India ${ }^{*}$ Corresponding Author : manikandan@kristujayanti.com

\begin{abstract}
Ipomoea quamoclit, a medicinal plant, known as a common medication for stomach ache, hemorrhoids and rheumatoid arthritis, has been employed for the biosynthesis of silver nanoparticles in the current study. The phytochemical analysis of this plant revealed that it is rich in phenolics, flavonoids, steroids, saponins, carbohydrates, triterpenes compounds. The present study has demonstrated an ecofriendly and safer method for developing a simple and cost effective production of silver nanoparticles using Ipomoea quamoclit flowers, leaves and seeds. The formation of nanoparticles was supported by color change and UV-Vis spectroscopy, showed maximum absorption peak at the range of 400-450 $\mathrm{nm}$. X-ray diffraction, Fourier transform-Infrared spectroscopy and Scanning electron microscope, demonstrated spherical and oval shaped nanoparticles in the sizes ranging between 25 and $45 \mathrm{~nm}$. The phytosynthesized silver nanoparticles have shown a remarkable antimicrobial activity against tested gram negative and gram positive pathogenic organisms such as Pseudomonas aeruginosa PAO1, Salmonella typhimurium, Serratia marcescens and Micrococcus luteus by conventional agar well diffusion in a dose dependent manner. The observations of the present investigation appear to be promising and offer a valuable agent for antimicrobial and antibiofilm activities. Among the various nanoparticles, the silver nanoparticles synthesized using the flower extract of Ipomoea quamoclit had a notably marked reduction in biofilm formation against Salmonella typhimurium. This paves the way in designing a new alternative therapeutic management of biofilm associated infections in future.
\end{abstract}

Keywords Nanoparticles; Ipomoea quamoclit; Antibiofilm; Antimicrobial; Human pathogens.

Introduction

Two major approaches were used for the synthesis of nanoparticles, namely, top-down and bottom-up. The chemicals used for nanoparticle synthesis are highly toxic, more expensive and non-ecofriendly that restricttheir use, predominantly in medical applications (1). The major advantages of using biological methods over chemical methods are their robustness, economic viability no use of toxic chemicals, no toxic byproducts and environment friendly nature (2-4). Nanoparticles are synthesized by utilizing the sources such as microorganisms, which include bacteria, fungi, mushroom, seaweed, or plant extracts, when compared with conventional chemical synthesis methods (5-10). Though microorganisms are exploited to synthesize nanoparticles, the rate of production is slow in comparison with the phytomediated synthesis. The importance of plant sources for the production of nanoparticles is still underrated (11-17). Several plants including the extracts of Tagetes sp.(marigold), Ziziphora tenuior, Abutilon indicum, Solanum tricobatum, Erythrina indica, Garcinia mangostana, Ocimum tenuiflorum, Spirogyra varians, Melia dubia, Acalypha indica and Sesuvium portulacastrum have been identified for the production of silver nanoparticles (AgNPs). The compounds present in the plant extract can act as reducing agents, converting $\mathrm{Ag}^{+}$to $\mathrm{Ag}^{0}$ and as capping agents of the AgNPs (18).AgNPs possess medicinal properties including antibacterial and antibiofilm activities, antifungal, antiviral, anticancer, anti-inflammatory, anti-angiogenesis and anti-platelet activities $(19,20)$. AgNPs exert their antimicrobial activity by disturbing the permeability, cell wall integrity, penetrating inside the bacterial cell wall, interacting with DNA, proteins and enzymes of the cell and blocking the activity of the enzymes $(20,21)$.

Ipomoea quamoclit, a perennial plant also known as Mayil Mannikkam, cypress vine or star glory has been used for decades as a conventional medicine to treat different types of diseases (22, 23), such as hemorrhoids, rheumatoid arthritis and stomach aches (24). The bioactive compounds present in the plant extract such as flavonoids, alkaloids, glycosides, tannins, terpenoids, saponins, proteins, carbohydrates and other phenolic compounds exhibit therapeutic properties. It possesses antioxidant activity, antiviral activity and neuroprotective activity, which are well known but its ability to produce AgNPs is not known. AgNPs are extensively used in medicine due to their large surface areas and high reactivity and are being successfully used in cancer diagnosis and treatment as well (18). Hence, in the present study, the synthesis of AgNPs was carried out using the natural aqueous extracts of Ipomoea quamoclit leaves, seeds and flowers to study the bactericidal and antibiofilm activities against Salmonella typhimurium, Pseudomonas aeruginosa PA01, Serratia marcescens and Micrococcus luteus. These pathogenic microorganisms are generally found on polluted water and food causing diarrhoea, 
fever and gastric enteritis, and on medical devices, forming biofilm on the surfaces causing pulmonary infections. Hence, the present study illustrated Ipomoea quamoclit as a nontoxic and ecofriendly bioresource for synthesizing AgNPs and evaluating the effects of the synthesized nanoparticles against various pathogenic microorganisms. The study also focused on determining the shape and size of the biosynthesized AgNPs. This could be a promising tool for minimizing the colonization of microbes on the surfaces and medical associated devices, which subsequently leads to infections; therefore, it is interesting to carry out this investigation while exploring the potential antimicrobial and antibiofilm properties using the phytosynthesized nanoparticles to overcome biofilm associated infections.

\section{Materials and Methods}

\section{Collection of sample and preparation of plant extract}

Fresh and healthy flowers/leaves/seeds of the perennial plant Ipomoea quamoclit were collected from the herbal garden of Sri Kaliswari College, Sivakasi, washed with water, air dried and powdered. About $10 \mathrm{~g}$ of Ipomoea quamoclit flower/leaf/seed powder was weighed respectively and mixed in $100 \mathrm{~mL}$ of sterile double distilled water. Ipomoea quamoclit (flowers/leaves/seeds) extracts were incubated at $70{ }^{\circ} \mathrm{C}$ for $15 \mathrm{~min}$. The boiled plant extracts were filtered using Whatmann paper. Then, $90 \mathrm{~mL}$ of $1 \mathrm{mM}$ silver nitrate was mixed with $10 \mathrm{~mL}$ of each boiled plant extract, respectively, incubated for $24 \mathrm{~h}$ and the color change was observed $(19,20)$.

Synthesis and characterization of silver nanoparticles using different parts of plant extracts

Different concentrations of aqueous silver nitrate were mixed with different ratios of phytoextracts (flowers/leaves/seeds), to improve the efficiency and yield of AgNPs. The mixed aqueous solutions were monitored at regular time intervals for the reduction of $\mathrm{Ag}$ by taking small aliquots $(1.0 \mathrm{~mL})$ and measuring absorbance in a UV-Visible spectrophotometer in the wavelength range of 200 to $800 \mathrm{~nm}$. The maximum absorbance of the synthesized nanoparticles was recorded using UV-Vis spectra. The colloidal solutions were spun at $1000 \mathrm{rpm}$ for $1 \mathrm{~h}$ and the pellets were air dried and dispersed in $1 \mathrm{~mL}$ of deionized water/DMSO. Finally, the purified phytosynthesized AgNPs were examined using analyses such as FTIR, SEM and X-ray diffraction (XRD) (25).

\section{Analysis of antimicrobial activity by well diffusion}

The AgNPs synthesized using Ipomoea quamoclit flower, leaf and seed extracts were tested for their antimicrobial activity against pathogenic organisms such as Pseudomonas aeruginosa PAO1, Salmonella typhimurium, Serratia marcescens and
Micrococcus luteus by agar well diffusion method. The pure cultures of the pathogenic organisms were initially subcultured on Muller Hinton broth at $37^{\circ} \mathrm{C}$ for overnight, followed by adding $10^{\circ}$ cells of each strain onto the Muller Hinton agar plates and wells were made by using gel puncture. Different concentrations of phytosynthesized AgNPs dissolved in DMSO were added onto the wells, incubated at $37^{\circ} \mathrm{C}$ for $18-24 \mathrm{~h}$ and the bactericidal activities were measured via zone of inhibition in $\mathrm{mm}$ (25).

\section{Analysis of antibiofilm activity}

The antibiofilm activity of the phytosynthesized AgNPs was studied using a 96 well microtiter plate. Biofilm production by clinical pathogenic strains grown in Luria broth (LB) and treated/untreated with nanoparticles was studied using a semi-quantitative adherence assay. Briefly, for control experiment, an equal number of cells of overnight grown culture were seeded in a 96-well microtiter plate and after incubation at $37^{\circ} \mathrm{C}$ for $24-48 \mathrm{~h}$, the biofilm plates were washed thrice with phosphate buffered saline to remove the free floating cells. The adhered cells were stained with $1 \%$ crystal violet for $15 \mathrm{~min}$, washed and air dried and resuspended in $200 \mu \mathrm{L}$ of $33 \%$ glacial acetic acid or ethanol. Biofilm formation was quantified by measuring the absorbance at $\mathbf{5 7 0}$ $\mathrm{nm}$. In another set, $100 \mu \mathrm{g}$ of AgNPs solution was added to the culture inoculum and the culture was grown overnight. The $200 \mu \mathrm{L}$ of treated sample was then seeded onto the microtiter plate and the same procedure was followed as mentioned above. The assays were performed in triplicates to test the biofilm inhibition $(9,34)$.

\section{Results and discussion}

Ipomoea quamoclit, a medicinal plant is used for various bioactivities around the world for various illnesses, which include antioxidant, antimicrobial, anticancer, anti-diabetic activities as well as insecticidal activity (24). Hence, this medicinal plant parts (flowers, leaves and seeds) were used for bioreduction, capping and stabilization of AgNPs.

\section{Confirmation of synthesis of silver nanoparticles}

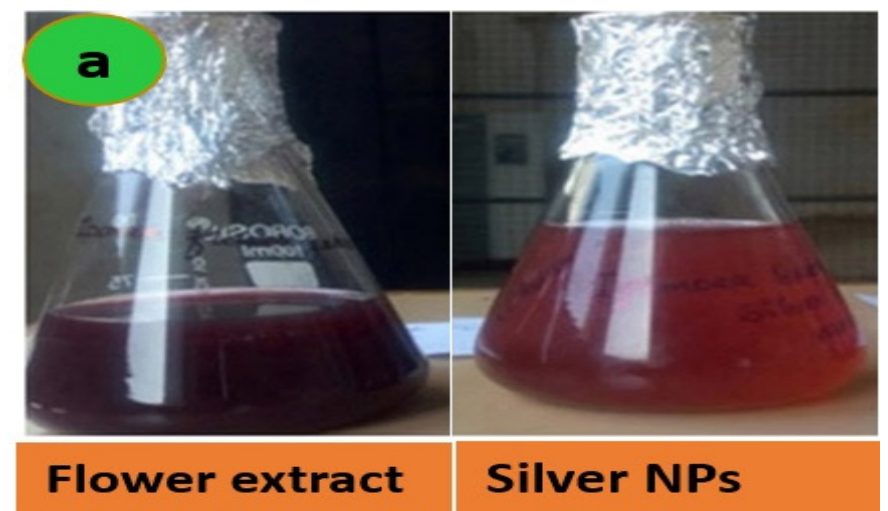




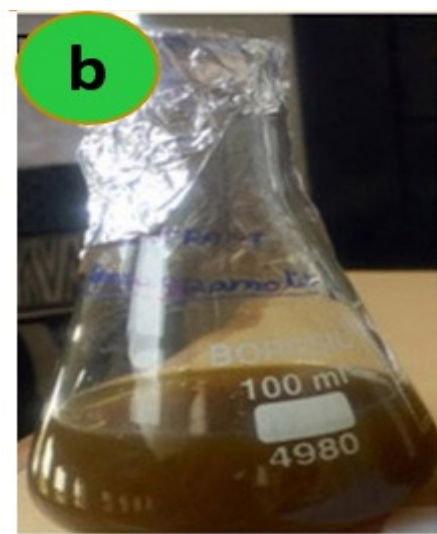

Leaf extract

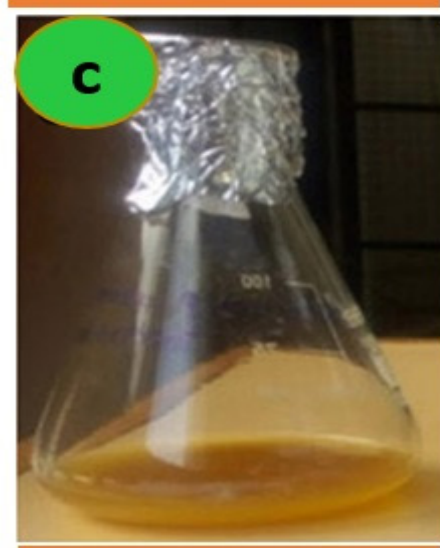

Seed extract

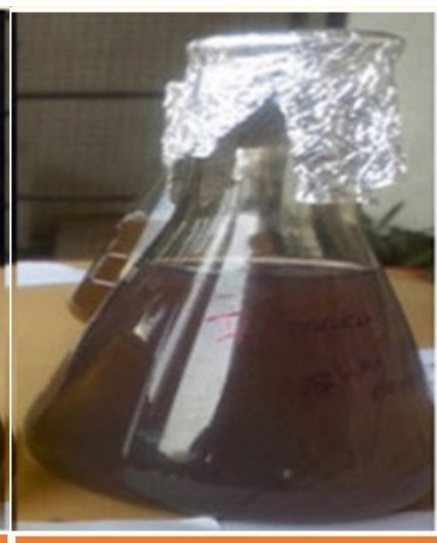

\section{Silver NPs}

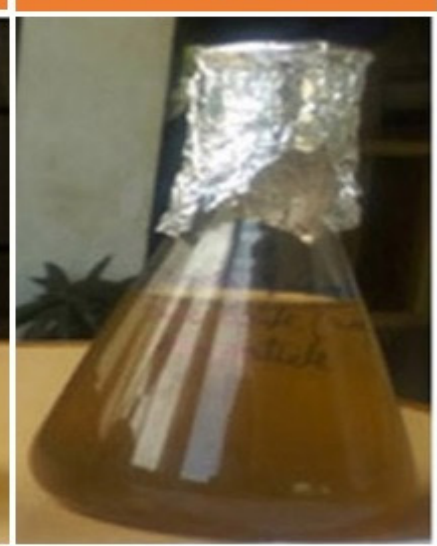

Silver NPs

Fig.1 Visual observation of color change upon formation of silver nanoparticles (a) Flower; (b) Leaf; (c) Seed AgNPs

Nanoparticles such as silver $(\mathrm{Ag})$, gold $(\mathrm{Au})$, osmium (Os), iridium (Ir), platinum (Pt) have been recognized to have the property of Surface Plasmon Resonance (SPR) due to their optical nature (26). The synthesis of AgNPs was observed by visual color change followed by UV-Vis spectroscopy. The colloidal solution changed color to dark reddish brown after $1 \mathrm{~h}$, indicating the production of AgNPs. The active molecules present in the flower extract aided in the reduction of $\mathrm{Ag}^{+}$into $\mathrm{Ag}^{0}$ (Fig.1a) and the AgNPs synthesized using Ipomoea quamoclit extracts were confirmed using UV-Vis spectrophotometer at various wavelengths. The UV-Vis spectrum of AgNPs synthesized using the flower extract of $I$. quamoclit had a maximum absorbance at $450 \mathrm{~nm}$, which signified the occurrence of AgNPs (Fig.2a). Similarly, the generation of AgNPs with the extract of leaf, showed that the color of the reaction mixture changed to light purple within $10 \mathrm{~min}$ and to dark purple after $3 \mathrm{~h}$, indicating the reduction of silver ions via the bioactive molecules present in the leaf extract (Fig.1b). The UV-Vis spectrum of the AgNPs synthesized using $I$. quamoclit had the maximum absorbance at 400 $\mathrm{nm}$, which specified the presence of silver nanoparticles (Fig.2b). The synthesis of AgNPs using the seed

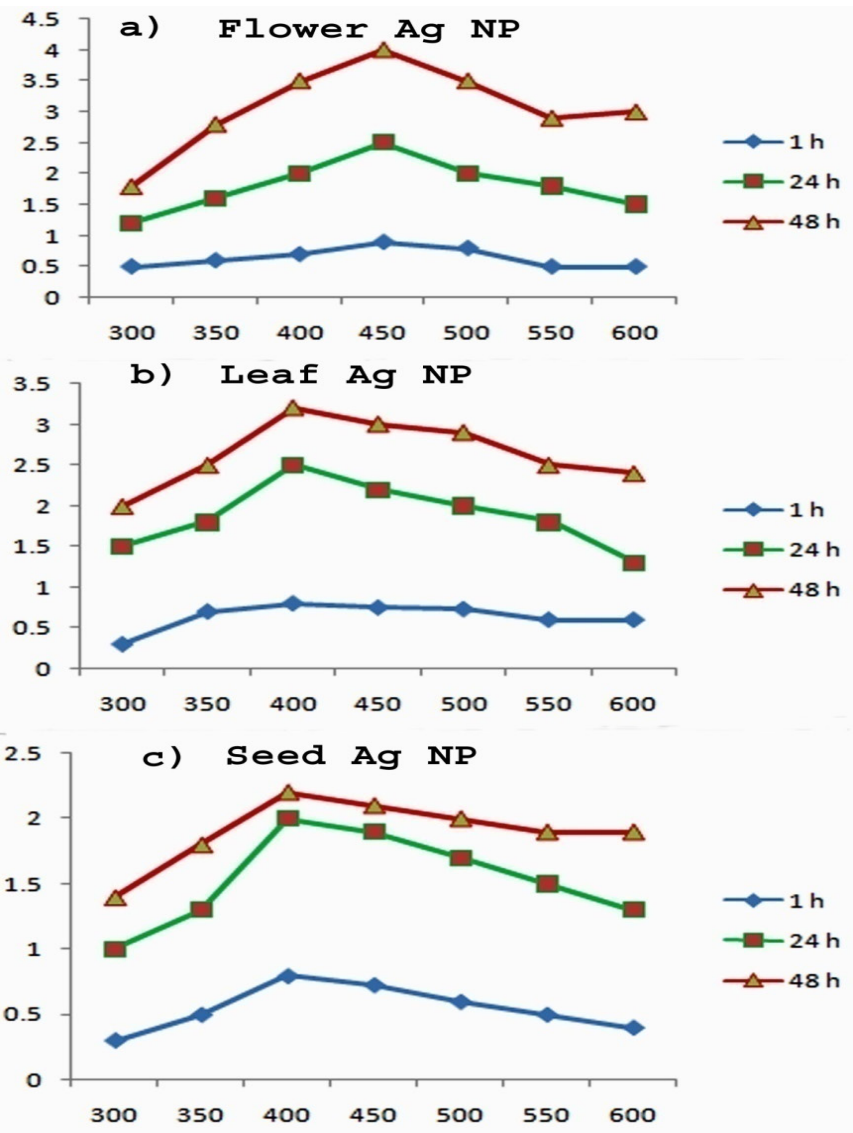

Fig.2 UV Visible absorption spectra of the synthesized silver nanoparticles using (a) Flower; (b) Leaf (c) Seeds of Ipomoea quamoclit

Table 1: Phytochemical analysis of Ipomoea quamoclit flower, leaf and seed extracts

\begin{tabular}{|c|c|c|c|c|}
\hline S.No & Phytochemical test & Flower extract & Leaf extract & Seed extract \\
\hline 1. & Alkaloids & + & + & + \\
\hline 2. & Flavonoids & + & + & + \\
\hline 3. & Terpenoids & _- & _ & + \\
\hline 4. & Cardiac glycosides & + & + & + \\
\hline 5. & Saponins & + & _- & + \\
\hline 6. & Phenols & + & + & _- \\
\hline 7. & Tannins & _- & _ & _- \\
\hline 8. & Carbohydrates & + & + & _- \\
\hline 9. & Proteins & - & + & + \\
\hline 10. & Steroids & + & _ & + \\
\hline
\end{tabular}

extract showed that the colour of the reaction mixture changed from yellowish brown and to dark brown after 1 $\mathrm{h}$, showing the production of AgNPs (Fig.1c). Further, the AgNPs had a maximum absorbance at $400 \mathrm{~nm}$, which confirmed the presence of silver nanoparticles (Fig.2c). Similar kind of results were observed in the reduction of $\mathrm{AgNO}_{3}$ to AgNPs using the Ipomoea digitata flower extract, the leaf extract of Calliandra haematocephala and the seed coat of Vigna mungo, which showed maximum absorption peak nearer at $\lambda_{\max }$ of $412 \mathrm{~nm}$, $414 \mathrm{~nm}$ and $421 \mathrm{~nm}$ respectively because of surface plasmon resonance (SPR) (27-29).

\section{Phytochemical analysis}


Plant source contains copious natural bioactive compounds such as steroids, alkaloids, flavonoids, saponins, tannins, and other nourishing compounds derived from various parts of the plant such as flowers, barks, seeds, leaves, stems, roots, shoots and the compounds acts as reducing and stabilizing agents for the synthesis of AgNPs (19). The analysis of phytochemicals in Ipomoea quamoclit (Table 1) showed the presence of phenolic compounds and other metabolites that aided in the reduction and stabilization of AgNPs.

\section{Morphology of silver nanoparticles}

The biosynthesized AgNPs were analyzed using SEM to envision the size and shape. The typical SEM images showed that the product mainly consisted of particles like silver nanoclusters with panoramic view and the size ranged from 150 to $200 \mathrm{~nm}$. However, further observations at higher magnifications revealed that the silver nanoclusters were assembled by smaller nanoparticles, which exhibited good uniformity and the average size of the nanoparticles synthesized from flower, leaf and seed extracts of Ipomoea quamoclit were about 43 to $45 \mathrm{~nm}, 16$ to $25 \mathrm{~nm}$ and 20 to $25 \mathrm{~nm}$ respectively (Fig. $3 \mathrm{a}-\mathrm{c}$ ).



Fig.3 SEM micrograph of the silver nanoparticles synthesized using (a) Flower; (b) Leaf; C) Seeds of Ipomoea quamoclit

\section{$X$-ray diffraction of silver nanoparticles}

XRD patterns of AgNPs showed atleast three main characteristic peaks observed at $2 \theta=28.24^{\circ}$, $32.46^{\circ}, 46.44^{\circ}$ for the flower extract, $28.20^{\circ}, 32.07^{\circ}$, $38.02^{\circ}$ for the leaf extract and at $37.82^{\circ}, 44.12^{\circ}, 77.70^{\circ}$ for the seed extract (Table 2), which confirmed the formation of AgNPs (Fig.4a-c), which were synthesized by treating the Ipomoea quamoclit flower, leaf and seed extracts with $1 \mathrm{mM}$ aqueous $\mathrm{AgNO}_{3}$ solution. Similar kind of observation has been reported in $(30,31)$ for the synthesis of AgNPs from fruit extract of the plant Bridelia retusa.
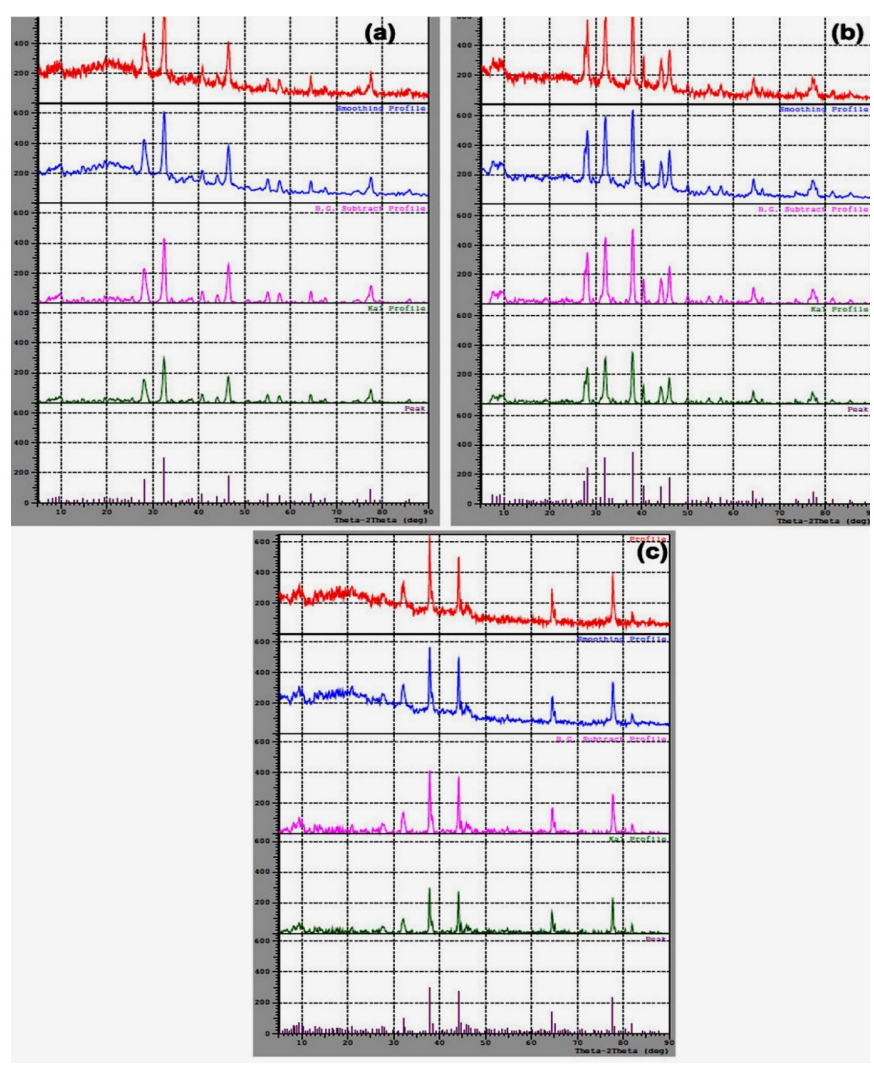

Fig.4 X-ray Diffraction pattern images of silver nanoparticles synthesized using (a) Flower; (b) Leaf; (c) Seed extracts of Ipomoea quamoclit

Table 2: X-ray diffraction of silver nanoparticles (Flower/Leaf/Seed Ag) showing the strongest 3 peaks

\begin{tabular}{lllllll}
\hline Peak & $\begin{array}{l}\mathbf{2} \boldsymbol{\theta} \\
\mathbf{( d e g})\end{array}$ & $\begin{array}{l}\mathbf{D} \\
\mathbf{( A g )}\end{array}$ & $\mathbf{I} / \mathbf{I I}$ & $\begin{array}{l}\text { FWHM } \\
\mathbf{( d e g})\end{array}$ & $\begin{array}{l}\text { Intensity } \\
\text { (counts) }\end{array}$ & $\begin{array}{l}\text { Integrated } \\
\text { Int } \\
\text { (counts) }\end{array}$ \\
\hline \multicolumn{2}{l}{ Flower Ag NPs } & & & & & \\
\hline 24 & 32.4655 & 2.75560 & 100 & 0.65110 & 178 & 1267 \\
36 & 46.4412 & 1.95373 & 59 & 0.64020 & 105 & 719 \\
23 & 28.2425 & 3.15729 & 52 & 0.97380 & 93 & 962 \\
\hline Leaf Ag NPs & & & & & \\
\hline 36 & 38.0222 & 2.36469 & 100 & 0.52220 & 209 & 1247 \\
32 & 32.0720 & 2.78850 & 89 & 0.60470 & 187 & 1129 \\
29 & 28.2000 & 3.16196 & 69 & 0.43140 & 144 & 730 \\
\hline Seed Ag NPs & & & & & \\
\hline 57 & 37.8204 & 2.37684 & 100 & 0.31880 & 179 & 648 \\
67 & 44.1220 & 2.05089 & 92 & 0.31370 & 164 & 515 \\
127 & 77.7038 & 1.22794 & 78 & 0.30350 & 140 & 417 \\
\hline
\end{tabular}




\section{FTIR analysis of silver nanoparticles}

The AgNPs synthesized using Ipomoea quamoclit flower/leaf/seed extracts were assessed by FTIR measurements to identify the functional groups responsible for capping and reduction. FTIR spectroscopy of the AgNPs showed major peaks at $3423 \mathrm{~cm}^{-1}, 1600 \mathrm{~cm}^{-1}, 1458 \mathrm{~cm}^{-1}, 1345 \mathrm{~cm}^{-1}, 1268$ $\mathrm{cm}^{-1}$ and $370 \mathrm{~cm}^{-1}$ which corresponded to $-\mathrm{NH}, \mathrm{C}-\mathrm{C}$ Stretch, amines, hydroxyl, S-S stretch and ether groups (Table 3), representing the occurrence of proteins and polyphenolics, which acted as reducing and capping agents for AgNPs, as inferred in the FTIR spectrum (Fig.5 a-c). These results suggested that the biomolecules present in $I$. quamoclit aided in the formation and stabilization of AgNPs in a colloidal medium (31).

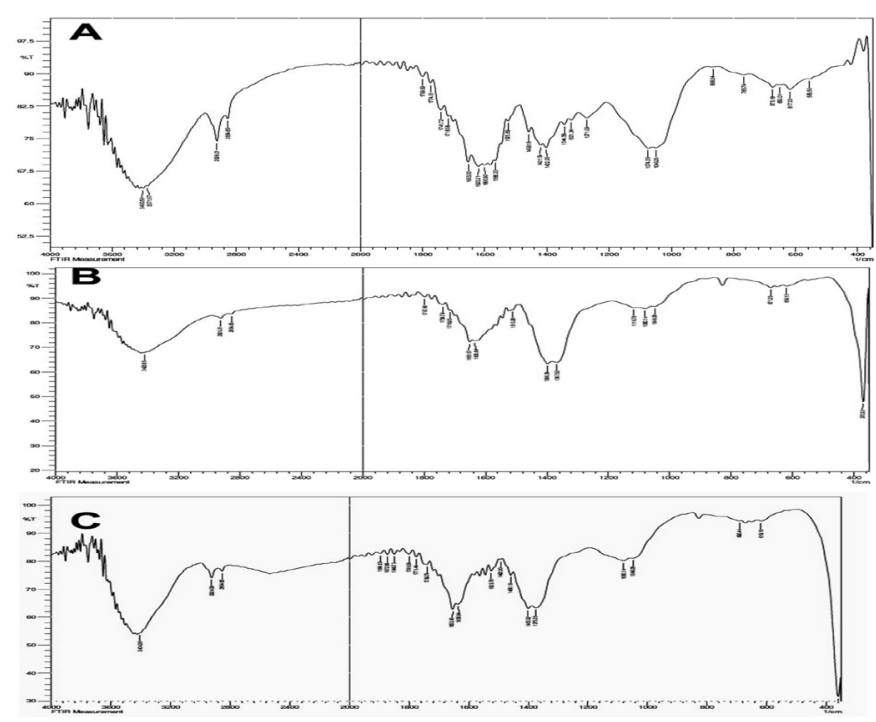

Fig.5 FTIR spectra of silver nanoparticles using (a) Flower; (b) Leaf; (c) Seed of Ipomoea quamoclit

\section{Antibacterial activity of silver nanoparticles}



Fig.6 Antimicrobial activity of silver nanoparticles using (a) Flower; (b) Leaf; (c) Seed of Ipomoea quamoclit against the tested pathogens using agar well diffusion assay

Table 3: FTIR spectrum of the silver nanoparticles synthesized by using Ipomoea quamoclit Flower/Leaf/Seed extracts

\begin{tabular}{ll}
\hline Group frequency wave number $\left(\mathrm{cm}^{-1}\right)$ & \multicolumn{1}{c}{ Functional group } \\
\hline $3400.50 / 3404.36 / 3423.65$ & NH stretch \\
3371.57 & NH stretch \\
$2924.09 / 2928.01 / 2926.01$ & Methylene C $-\mathrm{H}$ asym /sym .strech \\
2854.65 & Methylene C $-\mathrm{H}$ asym /sym .strech \\
$1716.65 / 1739.79 / 1799.50 / 1849.73$ & Ester \\
$1774.51 / 1896.03 / 1872.88$ & Ester \\
$1635.64 / 1651.07 / 1653.00$ & Alkyl C- C strech \\
$1600.92 / 1620.21 / 1799.59 / 1776.44$ & Alkyl C- C strech \\
$1510.26 / 1525.69 / 1566.20$ & Secondary amine, NH bend \\
1523.76 & Aromatic nitro compounds \\
1458.18 & Aromatic ring stretch/ Carbonate ion \\
$1421.54 / 1492.90$ & Carbonate ion \\
$1400.32 / 1402.25$ & Carboxylate (carboxylic acid salt) \\
$1344.38 / 1367.53 / 1375.25 / 1398.39$ & Nitrate ion \\
$1268.16 / 1271.09$ & Primary or secondary OH-plane bend \\
1116.78 & Secondary amine CN strech \\
$1074.35 / 1080.14$ & Organic silicone or silicone(Si-o-Si) \\
$1049.28 / 1090.14$ & Organic silicone or silicone(Si-o-Si) \\
866.04 & Peroxides , C-O-O-strech \\
765.74 & Aliphatic chloro compounds C-C1 strech \\
$671.23 / 673.16 / 697.44$ & Aryl thioethers C-S strech \\
619.15 & Aliphatic bromo compounds(Br-strech) \\
650.01 & Aliphatic bromo compounds C-Br strech \\
617.22 & Aliphatic bromo compounds C-Br strech \\
555.50 & Disulfides C-C strech \\
370.33 & Aryl disulfides (S-S strech) \\
\hline &
\end{tabular}

Antibacterial property of the synthesized AgNPs was tested against gram negative and gram positive bacteria namely Pseudomonas aeruginosa PA01, Salmonella typhimurium, Serratia marcescens and Micrococcus luteus by conventional agar well diffusion. The results indicated that the nanoparticles synthesized from flower/leaf/seed extracts of Ipomoea quamoclit have an antimicrobial activity against the tested pathogenic microorganisms. As the concentration of the nanoparticles increased, the zone of inhibition also increased (Fig.6 a-c; Table 4). Similar kind of dosage dependent zone of inhibition results were observed in the bactericidal action of AgNPs synthesized from leaf extract of Spondias dulcis, against gram negative human pathogens $S$. typhimurium and $E$. coli (32). Thus, it can be concluded that the antimicrobial activity of the synthesized nanoparticles increased in a dose dependent manner. Hence, the bactericidal activity of the AgNPs against the tested bacteria was most likely due to the attachment and interaction of the AgNPs to the cell membrane, DNA, RNA, proteins, enzymes, ribosomes, causing the production of free radicals and blocking the protein machinery leading to cell death $(1$, 20, 21).

\section{Antibiofilm activity of silver nanoparticles}


Table 4: Antibacterial activity of the silver nanoparticles synthesized using Ipomoea quamoclit Flower/Leaf/Seed extracts by agar well diffusion

\begin{tabular}{|c|c|c|c|c|c|c|}
\hline \multirow[b]{2}{*}{ S.No } & \multirow[b]{2}{*}{ Microorganisms } & \multicolumn{5}{|c|}{ Zone of inhibition (mM) } \\
\hline & & \begin{tabular}{|l|} 
Control \\
(Plant \\
extract)
\end{tabular} & \begin{tabular}{|l|} 
Negative \\
control \\
(DMSO)
\end{tabular} & $25 \mu \mathrm{L}$ & $50 \mu \mathrm{L}$ & $75 \mu \mathrm{L}$ \\
\hline \multicolumn{7}{|c|}{ Flower AgNPs } \\
\hline 1. & P. aeruginosa & - & - & 14 & 12 & 10 \\
\hline 2. & S. typhimurium & 7 & - & 7 & 10 & 12 \\
\hline 3. & S. marcescens & - & - & 10 & 12 & 14 \\
\hline 4. & M. luteus & 12 & - & 6 & 8 & 9 \\
\hline \multicolumn{7}{|c|}{ Leaf AgNPs } \\
\hline 1. & P. aeruginosa & - & - & 10 & 5 & 9 \\
\hline 2. & S. typhimurium & - & - & 3 & 6 & 12 \\
\hline 3. & S. marcescens & - & - & 10 & 12 & 14 \\
\hline 4. & M. luteus & - & - & 6 & 8 & 9 \\
\hline \multicolumn{7}{|c|}{ Seed AgNPs } \\
\hline 1. & P. aeruginosa & 6 & - & 10 & 8 & 7 \\
\hline 2. & S. typhimurium & 2 & - & 12 & 9 & - \\
\hline 3. & S. marcescens & - & - & 5 & 5 & 10 \\
\hline 4. & M. luteus & 6 & - & 10 & 10 & 8 \\
\hline
\end{tabular}

It is well known that biofilm is one of the major important virulence factors of the pathogenic organisms $(33,34)$. Several investigations have been made to report the antibiofilm activity of the AgNPs synthesized using phytomediated processes (34-38).
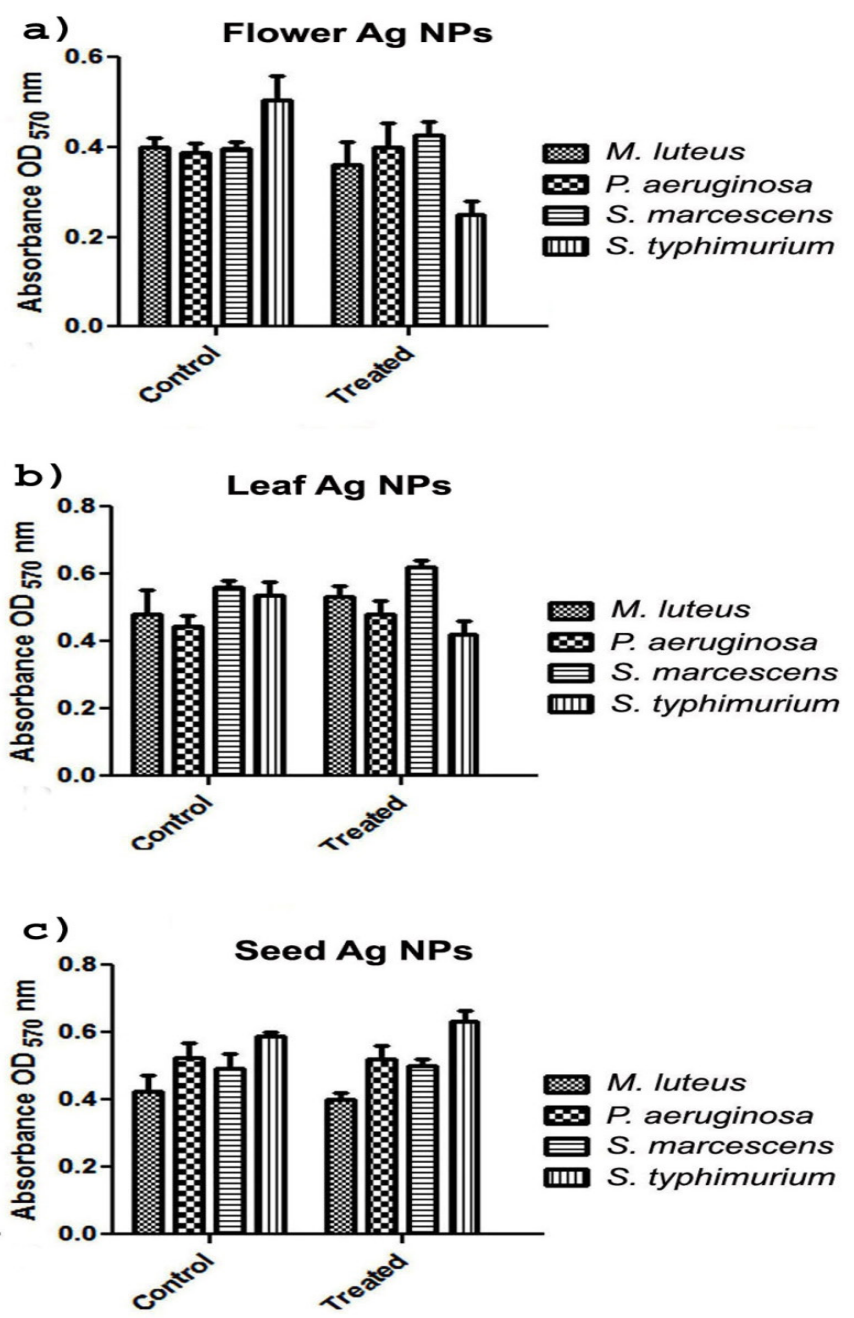

Fig.7 Antibiofilm activity of silver nanoparticles using (a) Flower; (b) Leaf; (c) Seed of Ipomoea quamoclit against the tested pathogens

Antibiofilm activity of the AgNPs synthesized using the flower, leaf and seed extracts of Ipomoea quamoclit were studied against the human pathogenic strains, Pseudomonas aeruginosa PAO1, Salmonella typhimurium, Serratia marcescens and Micrococcus luteus. Biofilm formation of the control organisms (untreated) and test (treated with nanoparticles) were studied in microtiter plates and stained with dye, dissolved and the absorbances were measured. Each experiment was carried out in four replicates. Among the nanoparticles, the AgNPs synthesized using the flower extract of Ipomoea quamoclit have notably marked reduction in biofilm formation against the pathogenic strain, Salmonella typhimurium (Fig.7 a-c). Based on the obtained results, it could be concluded that the AgNPs synthesized using I. quamoclit can be alone or in formulation with drug molecules be used as an effective antimicrobial agent or drug delivery agent. AgNPs produced using the biological source, I. quamoclit will have potentially less problems in applications compared to the chemical agents that are not ecofriendly, harmful with side effects and costlier and silver are more biocompatible and biodegradable and safer to use in the field of medicine.

\section{Conclusion}

The major threat posed by the antibiotic treatment is that the growing pathogenic bacteria become resistant to the given antibiotics and develop new mechanisms to evade the treatment. Therefore, there is an urgent need to find alternative and effective antibacterial agents against the pathogenic organisms. The antibacterial activity of the AgNPs has been extensively documented since they exhibit good physical, optical and natural properties, in medical applications. Nanoparticles biosynthesized using plant compounds are safe to useas biomedicine. AgNPs synthesized using the flower/leaf/ seed extracts of Ipomoea quamoclit, were capped with phenolic compounds, which would damage the bacterial cell wall, and in addition, generated free radicals and reactive oxygen species, posing damage and toxicity to the bacterial cells. The present study demonstrated that the AgNPs synthesized using Ipomoea quamoclit would be capable of providing a high antibacterial activity against the various tested pathogens and can have great potential for the preparation of antibacterial drugs. However, their bio-distribution and pharmacokinetics in clinical applications need to be investigated.

\section{Acknowledgment}

This research was supported by the College Management Trust, Kristu Jayanti College, Bangalore and Sri Kaliswari College, Sivakasi. We highly acknowledge them for supporting this research. We 
personally thank Dr. Karthik Rajendran for his genuine support and valuable suggestions.

\section{References}

1. Shanmuganathan, R., Karuppusamy, I., Saravanan, M., Muthukumar, H., Ponnuchamy, K., Ramkumar, V. S., \& Pugazhendhi, A. (2019). Synthesis of Silver nanoparticles and their biomedical applications-A comprehensive review. Current pharmaceutical design, 25(24): 2650-2660.

2. Saravanan, M., Barik, S. K., MubarakAli, D., Prakash, P., \& Pugazhendhi, A. (2018). Synthesis of silver nanoparticles from Bacillus brevis (NCIM 2533) and their antibacterial activity against pathogenic bacteria. Microbial pathogenesis, 116: 221-226.

3. Shanmuganathan, R., MubarakAli, D., Prabakar, D., Muthukumar, H., Thajuddin, N., Kumar, S. S., \& Pugazhendhi, A. (2018). An enhancement of antimicrobial efficacy of biogenic and ceftriaxone-conjugated silver nanoparticles: green approach. Environmental Science and Pollution Research, 25(11): 10362-10370.

4. Fathima, J. B., Pugazhendhi, A., Oves, M., \& Venis, R. (2018). Synthesis of eco-friendly copper nanoparticles for augmentation of catalytic degradation of organic dyes. Journal of Molecular Liquids, 260, 1-8.

5. Saravanan, M., Arokiyaraj, S., Lakshmi, T., \& Pugazhendhi, A. (2018). Synthesis of silver nanoparticles from Phenerochaete chrysosporium (MTCC-787) and their antibacterial activity against human pathogenic bacteria. Microbial pathogenesis, 117: 68-72.

6. Saratale, R. G., Saratale, G. D., Shin, H. S., Jacob, J. M., Pugazhendhi, A., Bhaisare, M., \& Kumar, G. (2018). New insights on the green synthesis of metallic nanoparticles using plant and waste biomaterials: current knowledge, their agricultural and environmental applications. Environmental Science and Pollution Research, 25(11): 1016410183.

7. Saratale, G. D., Saratale, R. G., Benelli, G., Kumar, G., Pugazhendhi, A., Kim, D. S., \& Shin, H. S. (2017). Anti-diabetic potential of silver nanoparticles synthesized with Argyreia nervosa leaf extract high synergistic antibacterial activity with standard antibiotics against foodborne bacteria. Journal of Cluster Science, 28(3): 1709-1727.

8. Suganthy, N., Ramkumar, V. S., Pugazhendhi, A., Benelli, G., \& Archunan, G. (2018). Biogenic synthesis of gold nanoparticles from Terminalia arjuna bark extract: assessment of safety aspects and neuroprotective potential via antioxidant, anticholinesterase, and antiamyloidogenic effects. Environmental Science and Pollution Research, 25(11): 10418-10433.

9. Pugazhendhi, A., Prabakar, D., Jacob, J. M., Karuppusamy, I., \& Saratale, R. G. (2018). Synthesis and characterization of silver nanoparticles using Gelidium amansii and its antimicrobial property against various pathogenic bacteria. Microbial pathogenesis, 114, 41-45.

10. Chellapandian, C., Ramkumar, B., Puja, P., Shanmuganathan, R., Pugazhendhi, A., \& Kumar, P. (2019). Gold nanoparticles using red seaweed Gracilaria verrucosa: Green synthesis, characterization and biocompatibility studies. Process Biochemistry, 80: 58-63.

11. Varadavenkatesan, T., Lyubchik, E., Pai, S., Pugazhendhi, A., Vinayagam, R., \& Selvaraj, R. (2019). Photocatalytic degradation of Rhodamine $B$ by zinc oxide nanoparticles synthesized using the leaf extract of Cyanometra ramiflora. Journal of Photochemistry and Photobiology B: Biology, 199: 111621.

12. Srinivasan, M., Venkatesan, M., Arumugam, V., Natesan, G., Saravanan, N., Murugesan, S., \& Pugazhendhi, A. (2019). Green synthesis and characterization of titanium dioxide nanoparticles (TiO2 NPs) using Sesbania grandiflora and evaluation of toxicity in zebrafish embryos. Process Biochemistry, 80: 197-202.

13. Jacob, J. M., John, M. S., Jacob, A., Abitha, P., Kumar, S. S., Rajan, R., \& Pugazhendhi, A. (2019). Bactericidal coating of paper towels via sustainable biosynthesis of silver nanoparticles using Ocimum sanctum leaf extract. Materials Research Express, 6(4): 045401.

14. Vasantharaj, S., Sathiyavimal, S., Saravanan, M., Senthilkumar, P., Gnanasekaran, K., Shanmugavel, M., \& Pugazhendhi, A. (2019). Synthesis of ecofriendly copper oxide nanoparticles for fabrication over textile fabrics: characterization of antibacterial activity and dye degradation potential. Journal of Photochemistry and Photobiology B: Biology, 191: 143-149.

15. Vasantharaj, S., Sathiyavimal, S., Senthilkumar, P., LewisOscar, F., \& Pugazhendhi, A. (2019). Biosynthesis of iron oxide nanoparticles using leaf extract of Ruellia tuberosa: antimicrobial properties and their applications in photocatalytic degradation. Journal of Photochemistry and 
Photobiology B: Biology, 192: 74-82.

16. Pugazhendhi, A., Prabhu, R., Muruganantham, K., Shanmuganathan, R., \& Natarajan, S. (2019). Anticancer, antimicrobial and photocatalytic activities of green synthesized magnesium oxide nanoparticles (MgONPs) using aqueous extract of Sargassum wightii. Journal of Photochemistry and Photobiology B: Biology, 190: 86-97.

17. Sathiyavimal, S., Vasantharaj, S., Bharathi, D., Saravanan, M., Manikandan, E., Kumar, S. S., \& Pugazhendhi, A. (2018). Biogenesis of copper oxide nanoparticles (CuONPs) using Sida acuta and their incorporation over cotton fabrics to prevent the pathogenicity of Gram negative and Gram positive bacteria. Journal of Photochemistry and Photobiology B: Biology, 188: 126-134.

18. Ahmed, S., Ahmad, M., Swami, B. L., \& Ikram, S. (2016). A review on plants extract mediated synthesis of silver nanoparticles for antimicrobial applications: a green expertise. Journal of advanced research, 7(1): 17-28.

19. Loo, Y. Y., Chieng, B. W., Nishibuchi, M., \& Radu, S. (2012). Synthesis of silver nanoparticles by using tea leaf extract from Camellia sinensis. International journal of nanomedicine, 7: 4263.

20. Daniel, S. K., Banu, B. N., Harshiny, M., Nehru, K., Ganesh, P. S., Kumaran, S., \& Sivakumar, M. (2014). Ipomea carnea-based silver nanoparticle synthesis for antibacterial activity against selected human pathogens. Journal of Experimental Nanoscience, 9(2): 197-209.

21. Geoprincy, G., Srri, B. V., Poonguzhali, U., Gandhi, N. N., \& Renganathan, S. (2013). A review on green synthesis of silver nanoparticles. Asian Journal of Pharmaceutical and clinical research, 6(1): 8-12.

22. Ho, K. L., Chung, W. E., Choong, K. E., Cheah, Y. L., Phua, E. Y., \& Srinivasan, R. (2015). Antiproliferative activity and preliminary phytochemical screening of Ipomoea quamoclit leaf extracts. Res $J$ Med Plant, 9: 127-134.

23. Paul, D., \& Sinha, S. N. (2016). An update on biological activities of medicinal plant Ipomoea quamoclit L. Trop Plant Res, 3(186): e190.

24. Renuka, K., Ravishankar, K. (2014). Preliminary phytochemical investigation and in vitro study of antioxidant antimicrobial and anticancer activities of ethanolic extract of Ipomoea quamoclit, World J. Pharm. Res. 3(8): 612-626.

25. Kumar, T. V. R., Murthy, J. S. R., Rao, M. N.,
\& Bhargava, Y. (2016). Evaluation of silver nanoparticles synthetic potential of Couroupita guianensis Aubl., flower buds extract and their synergistic antibacterial activity. 3 Biotech, 6(1): 92.

26. Ibrahim, H. M. (2015). Green synthesis and characterization of silver nanoparticles using banana peel extract and their antimicrobial activity against representative microorganisms. Journal of Radiation Research and Applied Sciences, 8(3): 265-275.

27. Varadavenkatesan, T., Selvaraj, R., \& Vinayagam, R. (2019). Dye degradation and antibacterial activity of green synthesized silver nanoparticles using Ipomoea digitata Linn. flower extract. International Journal of Environmental Science and Technology, 16(5): 2395-2404.

28. Raja, S., Ramesh, V., \& Thivaharan, V. (2017). Green biosynthesis of silver nanoparticles using Calliandra haematocephala leaf extract, their antibacterial activity and hydrogen peroxide sensing capability. Arabian journal of chemistry, 10(2): 253261.

29. Varadavenkatesan, T., Vinayagam, R., \& Selvaraj, R. (2017). Structural characterization of silver nanoparticles phyto-mediated by a plant waste, seed hull of Vigna mungo and their biological applications. Journal of Molecular Structure, 1147: 629-635.

30. Vinayagam, R., Varadavenkatesan, T., \& Selvaraj, R. (2017). Evaluation of the anticoagulant and catalytic activities of the Bridelia retusa fruit extractfunctionalized silver nanoparticles. Journal of Cluster Science, 28(5): 2919-2932.

31. Ramkumar, V. S., Pugazhendhi, A., Gopalakrishnan, K., Sivagurunathan, P., Saratale, G. D., Dung, T. N. B., \& Kannapiran, E. (2017). Biofabrication and characterization ofsilvernanoparticlesusingaqueous extract of seaweed Enteromorpha compressa and its biomedical properties. Biotechnology reports, 14: 1-7.

32. Yadav, P., Manjunath, H., \& Selvaraj, R. (2018). Antibacterial and dye degradation potential of zero-valent silver nanoparticles synthesised using the leaf extract of Spondias dulcis. IET nanobiotechnology, 13(1): 84-89.

33. Costerton, J. W., Lewandowski, Z., Caldwell, D. E., Korber, D. R., \& Lappin-Scott, H. M. (1995). Microbial biofilms. Annual review of microbiology, 49(1), 711745.

34. Kalishwaralal, K., BarathManiKanth, S., Pandian, 
S. R. K., Deepak, V., \& Gurunathan, S. (2010). Silver nanoparticles impede the biofilm formation by Pseudomonas aeruginosa and Staphylococcus epidermidis. Colloids and Surfaces $B$ : Biointerfaces, 79(2), 340-344.

35. Kumar, P., Senthamilselvi, S., Lakshmipraba, A., Premkumar, K., Muthukumaran, R., Visvanathan, P., \& Govindaraju, M. (2012). Efficacy of bio-synthesized silver nanoparticles using Acanthophora spicifera to encumber biofilm formation. Digest Journal of Nanomaterials and Biostructures, 7(2): 511-522.

36. Markowska, K., Grudniak, A. M., \& Wolska, K. I. (2013). Silver nanoparticles as an alternative strategy against bacterial biofilms. Acta Biochimica Polonica, 60(4).
37. Ali, K., Ahmed, B., Dwivedi, S., Saquib, Q., AlKhedhairy, A. A., \& Musarrat, J. (2015). Microwave accelerated green synthesis of stable silver nanoparticles with Eucalyptus globulus leaf extract and their antibacterial and antibiofilm activity on clinical isolates. PloS one, 10(7): e0131178.

38. Goswami, S. R., Sahareen, T., Singh, M., \& Kumar, S. (2015). Role of biogenic silver nanoparticles in disruption of cell-cell adhesion in Staphylococcus aureus and Escherichia coli biofilm. Journal of Industrial and Engineering Chemistry, 26: 73-80. 